\title{
BORIS AND GLEB: POLITICAL AND THEOLOGICAL IMPLICATIONS OF OVERCOMING VIOLENCE THROUGH SACRIFICE IN KIEVAN RUS‘
}

\author{
Simon Malmenvall
}

DOI: 10.17846/CL.2019.12.2.43-58

\begin{abstract}
MALMENVALL, Simon. Boris and Gleb: Political and Theological Implications of Overcoming Violence Through Sacrifice in Kievan Rus'. In the East Slavic historical consciousness, the sacrifice of the first canonized Rus' saints Boris and Gleb (died in 1015) came to be viewed as a reflection of the sacrifice of the Old Testament figure Abel and as a model of the imitation of Christ concerning the renouncement of secular power. The author of this article advocates the following thesis: the fact that the first canonized East Slavic saints came from the secular ruling elite testifies to the attempts of the Rus' literati to stress the strong influence of recently adopted Christianity on politically important decisions in Kievan Rus', which allegedly achieved its religious "maturity" within the context of salvation history through this. The existence of the martyrs among the secular ruling elite, however, cannot be viewed as a specific element of East Slavic medieval culture alone because this type of sainthood was, despite local differences, present in recently Christianized lands on the northern and eastern periphery of Europe at the time.
\end{abstract}

Keywords: Boris and Gleb, Kievan Rus', sainthood, violence, political theology, salvation history

\begin{abstract}
Abstrakt: MALMENVALL, Simon. Boris a Gleb: Politické a teologické dôsledky prekonávania násilia cez obetu v Kyjevskej Rusi. Obeta Borisa a Gleba (1015), prvých kanonizovaných svätých Kyjevskej Rusi, sa vo východoslovanskom historickom vedomí postupne začala vnímat ako obraz obety starozákonného Ábela a ako model napodobenia Krista v súvislosti s odmietnutím svetskej moci. Autor štúdie primárne obhajuje nasledovnú tézu: fakt, že prví kanonizovaní východoslovanskí svätí pochádzali z prostredia sekulárnej vládnucej elity svedčí o snahách kyjevských vzdelancov zdôraznit silný vplyv nedávno prijatého krestanstva na politicky dôležité rozhodnutia $\mathrm{v}$ Kyjevskej Rusi, ktorá tak údajne dosiahla náboženskú „dospelost" $\mathrm{v}$ kontexte dejín spásy. Existencia martýrstva v prostredí svetskej vládnucej elity ale nemôže byt vnímaná ako výhradný prvok východoslovanskej stredovekej kultúry, kedže tento typ svätosti bol napriek miestnym rozdielom prítomný $v$ danej dobe aj na iných nedávno pokrestančených územiach severnej a východnej periférie Európy.
\end{abstract}

Klúčové slová: Boris a Gleb, Kyjevská Rus, svätost', násilie, politická teológia, dejiny spásy

\section{Introduction}

The story of the two princely brothers Boris and Gleb is found in various narrative (literary) Rus' medieval sources, written in Church Slavic, which came to be known as the "Boris and Gleb cycle" (Борисоглебский иикл) in the Russian historiographical tradition. A group of the most comprehensive and also earliest testimonies, dating from the late eleventh to early twelfth 
centuries, consists of three texts: the report on Boris's death with the eulogy to the holy brothers included in the chronicle Tale of Bygone Years ${ }^{1}$ (Повльть времяньныхъ лють); the anonymous hagiography Tale and Passion and Encomium of the Holy Martyrs Boris and Gleb (Сказание, и страсть, и похвала, святую мученику Бориса и Гльба); and the hagiography by the monk Nestor from the Kiev Monastery of the Caves, Lesson Concerning the Life and Murder of the Blessed Passion-Bearers Boris and Gleb (Чтение о житии и погублении блаженую страстотерпию Бориса и Гльба). (Milyutenko 2006, 10, 57-58; Senyk 1993, 400-403) Among these three texts, Nestor's Lesson is the one that we shed further light on. ${ }^{2}$ The Christian testimony of the holy brothers with its political and theological implications is studied in line with semiotic textual analysis.

Surely not the earliest of these sources, but the second or the latest, is Nestor's Lesson. It is also stylistically and conceptually the most advanced of the entire Boris and Gleb cycle. (Milyutenko 2006, 57-58, 249-250, 257-260, 269-277; Shchapov 2003, 198-199; Podskalsky 1996, 187-188, 207; Senyk 1993, 227; Hollingsworth 1992, xxxiv-xxxvii) As far as the two other sources are concerned, there is no established consensus in the scholarship. However, a widely held view from the beginning of the twentieth century onwards ${ }^{3}$ shows that the report from the Tale of Bygone Years predates the anonymous Tale and Passion. On the other hand, some scholars ${ }^{4}$ suggest that the earliest of these sources is most probably the Tale, possibly written even before the first phase of Boris's and Gleb's canonization in 1072, thus serving as an apology of their formally not yet recognized holiness.

In historiography and literary scholarship, the study of the phenomenon of Boris and Gleb has a long tradition. Among earlier works, two that deserve special attention are those by the Russian literary historian Dmitri Ivanovich Abramovich (1873 - 1955) (1916) and Sergei Alekseevich Bugoslavsky (1888 - 1945) (2007). The latest Russian critical edition of the Boris and Gleb cycle was prepared by the literary historian Nadezhda Ilinichna Milyutenko (2006). In the English-speaking world, the most comprehensive study of the Boris and Gleb theme was carried out by the American cultural historian Paul Hollingsworth (1992; 2002). The inclusion of the Boris and Gleb theme is a standard rule in companions to medieval Rus' literature, where at least the German theologian Gerhard Podskalsky (1937 - 2013) (1996) and along with him the current Russian literary and cultural historian Aleksandr Nikolaevich Uzhankov (2011) deserve special mention.

\section{Historical background}

The first canonized Rus' saints Boris and Gleb, baptized as Roman and David, were sons of the Kievan prince Vladimir Sviatoslavich (980 - 1015), baptized as Vasili (Basil). Vladimir as the Kievan prince and the other Rus' princes belonged to the Rurik dynasty, which from the second

1 Passages and historical information based on the Tale of Bygone Years are cited from the Hypathian codex (Ипатьевский список/Ипатьевская летопись) of the mentioned source from the critical edition prepared by Donald Ostrowski (2004).

2 Passages and information based on the Tale and Passion and Lesson are cited from the recent critical edition of the Boris and Gleb cycle prepared by Nadezhda I. Milyutenko (2006); for Tale and Passion: (287-316); for Lesson: (357-402). The English text of the Lesson follows the critical edition and translation by Paul Hollingsworth (1992, 3-32).

3 This view is shared by scholars, such as (but not limited to): Shakhmatov (2001, 29-33, 53-54, 72-75, 385, 417-422), Müller (1967, xi-xvii), Hollingsworth (1992, xxxii-xxxiv, xxxvi-xxxvii, xxxix-xlii), Nazarenko (2003a, 44-45), and Milyutenko (2006, 10-11, 57).

4 Such as: Podskalsky (1992, 186-188), Poppe (1995), and Shchapov (2003, 197). 
Boris ANd Gleb: Political AND theological implications OF OVERCOMING VIOLENCE THROUGH SACRIFICE IN KiEVAN RUS'

half of the tenth century onwards ruled over all East Slavic territories. Being a successful military leader, Vladimir also became known as the "baptizer" (крьститель) of the East Slavs due to the adoption of Christianity from the Byzantine Empire as the state religion of Rus' in 988 or 989. At the time of Vladimir's death in 1015 , his older son Boris already ruled over the principality of Rostov, and the younger Gleb reigned ${ }^{5}$ over the principality of Murom. (Malmenvall 2015, 184190; Ostrowski 2004, 1020-1027; Uspenskiy 2000, 41)

Shortly before Vladimir's death in 1015, his son Yaroslav Vladimirovich, at the time prince of Novgorod and later of Kiev (1019 - 1054), started a rebellion against his father and stopped paying him tribute. Soon, however, the news reached Novgorod that Vladimir had died. Yaroslav persuaded the Novgorodians to join him in the struggle for the Kievan throne in order to stop the rampage of Vladimir's eldest son Sviatopolk, who in the meantime had taken the Kievan throne and had his younger brothers Boris and Gleb killed. (Malmenvall 2015, 190-191; Ostrowski 2004, 1023-1129) All of this contributed to the bloody strife that ensued among Vladimir's descendants, especially between Yaroslav and Sviatopolk. ${ }^{6}$ This was to become the first dynastic war in the Christian period of Kievan Rus'. In 1016 Yaroslav achieved victory over Sviatopolk and gained control of Kiev. However, this victory was short-lived because Sviatopolk entered into an agreement with the Pechenegs, at whose hands Yaroslav's forces suffered a crushing defeat, forcing him to retreat to his hometown of Novgorod. Along with the Pechenegs, Yaroslav's troops were also pursued by the Polish forces under the leadership of King Bolesław the Brave (992 - 1025), another of Sviatopolk's allies. Thus, in 1017 Kiev was again in Sviatopolk's hands and at the same time under Polish protection. However, in 1019 Sviatopolk was finally defeated by Yaroslav in the Battle of the Alta River east of Kiev. The defeated Sviatopolk fled together with the Poles. This allowed Yaroslav to resume rule over the western half of Rus', and then in 1036, after the death of his brother Mstislav, he extended his rule over all Rus' territory. (Malmenvall 2015, 191-192; Ostrowski 2004, 1129-1161, 1190-1192; Senyk 1993, 225-228)

\section{Christian testimony of Boris and Gleb}

Regarding the facts and chronology given in the narrative, the Lesson could, at least at first glance, be dependent on the anonymous Tale and Passion, yet there is no direct evidence that Nestor used any native literary sources. (Hollingsworth 1992, xxxv) Even so, the composition of the narrative written by the monk Nestor represents his own interpretation of events with its complete internal logic. This hagiography stands out among the other works of the Boris and Gleb cycle thanks to its in-depth historical and theological reflection and stylistic elaborateness. The Lesson is also characterized by expressive narration, saturated with biblical reminiscences. (Milyutenko 2006, 256-257, 269; Senyk 1993, 401)

Nestor's Lesson consists of two parts: the hagiography in earnest, which provides the relation on the death of the two princely brothers, and the report on the miracles, representing the initial

5 The claim about Boris' rulership over Rostov and Gleb's over Murom is based on information given in the chronicle Tale of Bygone Years, the most extensive narrative source of the Kievan period, and in the anonymous hagiography Tale on Boris and Gleb. However, according to the Russian historian Alexander V. Nazarenko (2003a, 44-47) and based on the context of Nestor's Lesson, Boris ruled over Vladimir in Volyn, while Gleb, due to his young age, lived with his father in Kiev.

6 Although Sviatopolk was the eldest living son of Vladimir Sviatoslavich and might at first glance be perceived as a rightful successor, according to the native Rus' sources (Tale of Bygone Years and the Boris and Gleb cycle) Sviatopolk's taking of the throne was accompanied by deception and deliberate violencehe treacherously killed off his brothers to ensure his position. 
stage of spreading their cult up until the 1070s. The Lesson begins with an extensive historical digression, in which the author lists the main spiritual (biblical) milestones from the creation of the world up to his own time. This digression reflects a typical medieval Christian belief that the historical process is a struggle between good and evil, God and the Devil, but in which God eventually rises as the final victor. Nestor claims that, whereas the Devil had induced people to worship idols, God sent them prophets that were eventually killed. At a specific historical moment, God's mercy rose to such a level that He sent His only Son to the Earth. After mentioning the birth, death, and resurrection of Christ, Nestor stops at the preaching of the Apostles, resorting to the Gospel parable of the workers of the eleventh hour ("in the last days") (cf. Matt. 20:116), comparing it to the relatively late adoption of Christianity in Kievan Rus" under the rule of Vladimir Sviatoslavich. (Milyutenko 2006, 360; Uspenskiy 2000, 48-49; Podskalsky 1996, 194195; Hollingsworth 1992, xxiii, xxxiv-xxxv)

According to Nestor's understanding, after the resurrection of Christ the fight between good and evil continued with new intensity. After the official Christianization, the "two bright stars" (Milyutenko 2006, 362) from the Rurik dynasty-Boris and Gleb-were confronted by Sviatopolk, into whose heart "the Devil had gained entrance," (364) unable to accept the weakening of paganism due to the spread of Christianity.

As the Devil had convinced people to worship idols and kill the prophets before, so he now compelled Sviatopolk to fratricide: the killing of the two innocent brothers Boris and Gleb, as the Rus' figures corresponding to the Old Testament figure Abel. Sviatopolk, the Rus' Cain, had submitted himself to the idol, which caused his deviation from God and those close to him (in the first place, his own brothers), this idol being the lust for power. In the light of such understanding, not starting an armed rebellion against Sviatopolk is regarded as a victory of the holy brothers over the Devil, which in turn enables Nestor to compare the deeds of Boris and Gleb to Christ's sacrifice on the cross. Such a description further allows the martyrdom of the princely brothers to gain a broader historical and theological significance. The recent historical experience of Kievan Rus' was thus placed in the biblical context of God's providence. Just as, according to Genesis, the history of mankind after the expulsion from Paradise experiences its new (spiritual) turning-point with Cain's fratricide and Abel's sacrifice, so the history of Rus' after Christianization experiences its new (spiritual) turning point with Sviatopolk's crime and the holiness of Boris and Gleb. (Paramonova 2010, 269-270; White 2010, 107; Milyutenko 2006, 258-260, 262; Uspenskiy 2000, 32-35, 38-39, 47; Podskalsky 1996, 195) In this context, it should be emphasized that the general comparison between the sacrifice of Abel and the sacrifice of the two princely brothers and its actualization in relation to the relatively recent developments in Kievan Rus' is entirely made by Nestor. Even though Nestor seems to derive this comparison from the Book of Genesis (4:1-16), he does not regard the fact that Abel did not sacrifice himself knowing that Cain wanted to kill him, and so, from the narrow literal point of view, there is no such similarity between Boris and Gleb, on the one hand, and Abel, on the other. Boris and Gleb as innocent victims were not simply murdered by their older brother, but voluntarily sacrificed themselves in order to prevent further bloodshed and "save many lives." (Milyutenko 2006, 370, 372, 374) In addition, the comparison between Abel and the princely brothers is later (at least partly) relativized by Nestor himself. Namely, Nestor claims that Gleb does not fight Sviatopolk's men initially because he thought that by giving himself up he would be taken peacefully to Sviatopolk and his retinue would be spared.

In comparison to other medieval European polities, the official adoption of Christianity in Kievan Rus' was one of the latest, preceding only the Scandinavian lands (between the late tenth and late eleventh centuries) and the Great Principality of Lithuania (second half of the fourteenth century). For a broader historical context, see: Berend (2007) and Rowell (1994). 
Boris ANd Gleb: Political AND theological implications OF OVERCOMING VIOLENCE THROUGH SACRIFICE IN KIEVAN RUS'

Later, when Gleb realizes that he is about to die, according to Nestor's assertions, he compares himself with the biblical Zechariah, not with Abel. (374)

The moments before Boris's death are depicted by Nestor with dramatic escalation, in which the most significant are repeated warnings of Boris's retinue (druzhina) about Sviatopolk's intention, suggesting two options to Boris: to either escape or resist with force.

Then the warriors with him, those who had gone against the armies (there were some eight thousand, all armed), said to him, "Lord, we were entrusted to you by your good father. Let us go, either with you or alone, and thus drive that one out by force from the town; and we will lead you in, as your good father committed you to us." Hearing this, the blessed one, truly merciful and concerned for them as for his own brothers, said to them, "No, my brothers, no, men of my father, do not so anger the Lord, my brother, lest he raise civil strife against you. Better is it for me to die than for so many souls to perish." (Hollingsworth $1992,13)^{8}$

Boris voluntarily chooses a third option: to sacrifice himself in order to prevent further bloodshed and "save many lives." He then embarks on a journey to Kiev, submitting himself to the will of Sviatopolk. During the journey he sets up a tent, in which by praying he makes his preparations for death and is ultimately killed the next day at dawn. Boris spends the night reading Bible passages and praying. Upon hearing the murderers closing in, Boris instructs his priest to begin the morning liturgy. At the end of the liturgy, Boris says goodbye to his escort and lies down in the tent. Boris is then pierced by the spears together with one of his servants. Thinking that Boris is already dead, the killers leave the tent. However, the prince, half-conscious, jumps out of the tent, pronounces a prayer to God to thank Him for the martyrdom he has received, and only then breathes his last breath. The body of Boris is then transferred to Vyshgorod and buried beside St. Basil's Church. (Milyutenko 2006, 262-265)

According to the Lesson, at the time of Vladimir's death Gleb, his youngest son, was in Kiev. When he learns about Sviatopolk's intention to kill Boris, Gleb decides to flee north to the "other brother," probably the Novgorodian prince Yaroslav. After Boris's death, Sviatopolk orders his men to pursue the fleeing Gleb, and they soon catch him in his boat. ${ }^{9}$ Gleb's retinue is willing to defend their prince. Gleb, however, instructs them to withdraw to the river bank and leave him alone with the servants because he is convinced that this will be enough for the attackers to take him peacefully to his older brother in Kiev and let his retinue escape without a fight. However, the assassins take over the boat and then order Gleb's cook to cut his lord's throat. At this point, Nestor draws attention to the contrast between the faithful servant of Boris, who-although to no avail-tried to protect him with his own body, and Gleb's treacherous cook, who murdered his lord and thus became like Judas Iscariot. In his last prayer before his death, Gleb compares himself

8 Таче отвъщаша сущии с нимъ вои, иже бъша ходиль на ратныя, бъ бо ихъ акы до 8 тысящь, вси же во оружии, глаголаша ему: “Мы, о, владыко, предани есмы благымъ отцемъ твоимъ в руцъ твои. Идемь или съ тобою, или едини, и тако того нужею ижденемь из града, а тебе же въведемъ, яко же преда насъ тебе благы отець твои.” Си слышавъ, блаженыи, по истинъ милосердыи, пекыся о нихъ, акы братьи своеи, глагола имъ: “Ни, братие моя, ни, отци, не тако прогнъваите господа моего брата, еда како на вы крамолу въздвигнеть. Нъ уне есть мнъ одиному умрети, нежели толику душь." (Milyutenko 2006, 370)

9 Nestor provides no exact location. Judging from other texts of the Boris and Gleb cycle, Tale and Passion (Milyutenko 2006, 298, 300) and Tale of Bygone Years (Ostrowski 2004, 1080-1082), Gleb was probably caught at the place near Smolensk where the Smiadina River flows into the Dnieper. 
to the righteous Zacharias of the Old Testament (cf. Matt. 23:35; Luke 11:51), assassinated in front of the altar in the Jerusalem temple.

"My Lord, Jesus Christ, hear me this hour and vouchsafe me to share of the company of Thy saints. For, O Lord, even as once this day Zechariah was slaughtered before Thine altar, so now also am I slaughtered before Thee, O Lord. O Lord, Lord, remember not my former transgressions, but save my soul, so that the deceitful counsel of my adversaries may not block its way, and let Thy bright angels receive it." /... / When holy Glěb had said this, the cook kneeled, seized the head of the holy one, and slit his throat. (Hollingsworth $1992,16)^{10}$

After reporting on Gleb's death, Nestor briefly stops at Sviatopolk's unfortunate end. His earthly and spiritual destruction is compared with the fate of Roman Emperor Julian the Apostate (361 363). Yaroslav's victory in the Battle of the Alta River, however, is not mentioned as the cause of such a fate, but rather the fact that Sviatopolk died a violent death "in foreign countries," where he was "expelled by a throng." (Milyutenko 2006, 261, 265-267; Uspenskiy 2000, 36-39; Podskalsky 1996, 195)

The last part of Nestor's Lesson consists of a report on the discovery of Gleb's remains and on the wonders that have allegedly taken place thanks to the intercession of the princely brothers, thus confirming their sanctity. When Yaroslav assumes control over the Kievan throne he orders that the remains of Gleb's body be found. Even after a long search, Yaroslav's trackers do not find a single clue; however, a year later a hunting party from Smolensk stumbles upon the fully preserved body and notify the city elder, who departs for the site of Gleb's death, puts it under guard, and reports the incident to Yaroslav. The Grand prince sends him a letter ordering the body to be transferred in Vyshgorod and buried together with Boris. The Lesson ends with an extensive eulogy to the holy brothers. (Milyutenko 2006, 267-269; Podskalsky 1996, 196)

\section{Sainthood of the princely brothers and its political and theological implications}

Among the local Rus' saints, the cult of Boris and Gleb was the oldest and most widespread. The first phase of the canonization of the princely brothers, limited to the level of popular worship, was concluded by the confirmation of the Kievan metropolitan Georgi in 1072. At that time, the transfer of their relics took place: from St. Basil the Great Church in the town of Vyshgorod north of Kiev to a new stone church (also built in that town). (Ostrowski 2004, 1462-1473) It is 1115 , however, that can be regarded as the second and final phase of the canonization because their relics were translated to an even newer and larger church, dedicated to the princely brothers and built on the same site. From that year onwards, their main memorial day was liturgically established to be celebrated on July 24 th. ${ }^{11}$ It cannot be excluded-although not directly proved

10 “Господи мои Исусе Христе, услыши мя в часъ сеи и сподоби мя причастнику быти святыхъ Твоихъ. Се бо, о Владыко, яко древле в сии день Захария заколенъ быстъ предъ требником твоимъ, и се нынъ азъ закланъ быхъ предъ Тобою, Господи. Нъ, Господи, Господи, не помяни моихъ первыхъ, нъ спаси душю мою, да не срящеть ея лукавы съвътъ противныхъ, нъ да приимуть ю ангели Твои свътлии." /.../ Си святому Глъбу рекшу, и се же прежереченыи поваръ, ставъ на колъну, закла и главу святому и преръза гортань его. (Milyutenko 2006, 374, 376)

11 The secondary memorial day was celebrated on May 2nd, the anniversary of the transfer of their relics in 1115 . 
Boris ANd Gleb: Political AND theological implications OF OVERCOMING VIOLENCE THROUGH SACRIFICE IN KIEVAN RUS'

either-that in the following decades the cult of Boris and Gleb spread beyond the borders of Kievan Rus'to the territories of Bohemia, Byzantium, and Serbia. (Milyutenko 2006, 5, 5455, 58, 279-282; Nazarenko 2003b, 54-55; Uzhankov 2000, 32-38, 45-46; Senyk 1993, 229-231; Hollingsworth 1992, xxvi-xxvii)

The first politically significant confirmation of the martyrdom of the princely brothers can already be seen in the mid-eleventh century. It was then that in honor of the first Rus' passionbearers the grandsons of the reigning grand prince, Yaroslav Vladimirovich, were given the names Roman (in honor of Boris) and Gleb at their baptism. (Ostrowski 2004, 1296-1297, 1457-1462, 1641) Nevertheless, the cult of Boris and Gleb did not start to develop its prominently political dimension before the end of the eleventh century. This was a time of frequent internal dynastic conflicts, the division of Rus' territory among strengthening individual half-independent principalities, and the consolidation of the all-Rus' Orthodox Church (the Kiev metropolitanate) as a religious and political institution preserving the (symbolic) unity of the East Slavic territories. ${ }^{12}$ From then on in the consciousness of East Slavic writers and Church dignitaries, Boris and Gleb became increasingly present as the protectors of the Rurik dynasty, intercessors for peace, and guardians of the homeland. The clearest testimony about the increasing political importance of the cult of the princely brothers can be seen in Nestor's Lesson. The voluntary sacrifice of Boris and Gleb is not shown solely as a martyrdom for Christ and the first case of the veneration of local East Slavic saints, but as a commendable patriotic act as well, which places it in the context of resolving the current political issues of the time. (Litvina and Uspenskiy 2006, 11, 13, 18-19, 43, 52; Milyutenko 2006, 5, 271-272, 279-280; Nazarenko and Turilov 2003, 52-53; Poppe 2003, 42, 44, 46; Hollingsworth 1992, xiv-xvi, xxvii-xxxi, lv-lvi) This does not imply that Yaroslav Vladimirovich, who already from the beginning refused to submit to his older brother Svjatopolk, acted "unpatriotically." Although Yaroslav's active engagement in the struggle for political power was, according to Nestor, not morally equal to the utmost exemplary Christian "heroism" of Boris and Gleb (renouncement of earthly goods and giving one's life for others), Yaroslav's struggle and its final outcome was eventually justified as a patriotic act as well. Yet, it was not defined in ideal religious terms, but in accordance with the more secular imagery of a good prince. He came to be seen as a savior of his father's heritage and protector of Kievan Rus' from the "accursed" Sviatopolk_-like Boris and Gleb, he was fighting evil for the sake of his homeland, but with different, more "earthly" means. In this context, it can be said that Yaroslav acted as a good prince, whereas Boris and Gleb also acted like saints imitating Christ. ${ }^{13}$

Nestor highlights two main merits of the passion-bearers Boris and Gleb: following the example of Christ's peacefulness in not fighting evil through violence, but through voluntary sacrifice of oneself for others, "saving many lives," and mitigating the consequences of the later dynastic conflict; and not submitting oneself to the lust for ephemeral earthly goods (in this case, political power), but rather aspiring for eternal "heavenly glory." (Milyutenko 2006, 271, 272274, 276-277; Hollingsworth 1992, xxi, li-lii) Despite the undeniable recognition of the holiness of the two brothers, in his Lesson Nestor recalls Gleb's initial cowardice and, consequently, moral inferiority in relation to the older and apparently more mature brother, Boris. Gleb's flight from Sviatopolk in an attempt to save his own life is seen as resisting the will of God and is placed in contrast with Boris's resoluteness in his decision on the eternal "heavenly gifts." In the understanding of Nestor's Lesson, the example of Boris relinquishing his own life

12 Regarding the development of ecclesiastical structures and their role in Rus' society between the tenth and twelfth centuries, see Malmenvall (2016).

13 On the ideal conduct of the prince towards the political community and the Church, see Fedotov (1965, 268-273, 301-303). On the general traits of political ideology in Kievan Rus', see Chichurov (1990). 
takes the shape of a political warning, applicable to the conduct of some of the Rus' princes in the second half of the eleventh century, who in their struggles for power often fled to foreign lands, only to return home with foreign armies, aided by which they eventually achieved victories not only against their own countrymen, but against members of their own dynasty as well. ${ }^{14}$ Therefore, Boris as a saintly type does not fall within the scope of remote religious ideals; instead, he represents an attempt to provide an answer to the real political dilemmas of the time in which this hagiography was written. The entire narrative flow of the Lesson is constructed so as to clearly express one single idea: to remind the Rus' princes what their moral stance should look like and what their political priorities should be. Boris's and Gleb's love for God and their imitation of Christ is thus realized in evident care for those close to them, which, in turn, means honoring their patriotic responsibility to all of Kievan Rus'. The princely brothers are venerated by Nestor because of their consistent performance of both religious and patriotic duties, which enables them to show the right way for future generations as the first canonized Rus' saints. Their example shows that a virtuous prince does not leave his homeland and does not fight for power without consideration of the price paid in lives by other people-not only his relatives, but also the "common people." Therefore, the tradition of stories about the holy passion-bearers and telling about miracles caused by their intercession serves as an appeal to the Kievan Rus' princes to stop their fratricidal conflicts and subordinate their interests to the welfare of those close to them that live in the common homeland of Rus', and, consequently, become genuine Christians, and not in name only. (Paramonova 2010, 270-271; Milyutenko 2006, 270, 273-277; Uspenskiy 2000, 42; Podskalsky 1996, 70-71, 436; Senyk 1993, 232-234; Hollingsworth 1992, lii-lvi)

Taken as a whole, the texts belonging to the Boris and Gleb cycle are also a testimony about the profound reflection on the position of Kievan Rus' within the community of Christian polities, especially in relation to its spiritual "teacher" Byzantium, whose example encouraged the East Slavs to adopt the Christian faith. The interpretation of patriotic enthusiasm provided by the voluntary sacrifice of Boris and Gleb does not end with their political example in relation to the Rus' princes lacking a sense of common cause. It also concerns the self-esteem of the bearers of Rus' culture-the local Church and the secular elite-within the international context in comparison with the polities boasting a Christian tradition much older than the one in the "young" Kievan realm. ${ }^{15}$ An important general feature of the story of the first Rus' saints found in various texts of the Boris and Gleb cycle is the presence of many biblical passages and reminiscences. The parallels with biblical events and personalities testify about the desire of the East Slavic writers of the time to seek through them a confirmation that God's providence has been reflected in the recent history of Kievan Rus' as well. The martyrdom of Boris and Gleb is thus primarily seen as a historically and geographically specific re-realization of the Old Testament story of Abel and Cain. In this way, Kievan Rus' was portrayed as included in the global providentialistic process of salvation history and as a full-fledged part of the Christian community. It is this ideational emphasis that places the Boris and Gleb cycle (especially Nestor's Lesson) together

14 In addition to Sviatopolk's alliance with the Polish king, two similar cases are also known. Prince Izyaslav Yaroslavich used this instrument twice, in 1069 and 1077, when he took over Kiev with the aid of Polish forces (Ostrowski 2004, 1383-1396, 1604-1606). In 1079 Kievan Rus' was invaded by Prince Roman Sviatoslavich, whose allies were the steppe pagan nomads known as the Polovtsi or Cumans; he eventually gained back his heritage, the principality of Chernigov (1641-1643).

15 This thesis can be compared with the observation in Norman W. Ingham (1984, 37). He claims that the sainthood of the two princely passion-bearers (and also Wenceslaus of Bohemia-more on him below) marked the symbolic culmination of the first period of Christianity and showed God's favor and the "coming of age" of the "nation", that is, the (ethno-)political community of which the princely passion bearers became the heavenly protectors. 
Boris ANd Gleb: Political AND theological implications OF OVERCOMING VIOLENCE THROUGH SACRIFICE IN KiEVAN RUS'

with two other historically important and conceptually advanced literary texts from the Kievan period: Sermon on Law and Grace (Слово о законг и благодютии) by metropolitan Ilarion from the mid-eleventh century, and Tale of Bygone Years from the early twelfth century-both of them try to give a meaning to the relatively recent history of Rus', referring to God's providence and fostering patriotic feelings. ${ }^{16}$ The main conceptual point of the Boris and Gleb cycle in this context refers to the patriotic self-esteem of the Rus' elite. The later in relation to other Christian polities, in particular the "teacher" Byzantium, saw their homeland-despite its relatively late official adoption of Christianity - as religiously "mature" and therefore an equivalent of the others. This was also possible due to the emergence of the first local saints. Hence emphasizing the fact of the principle of love towards one's enemies made it into the acts of the representatives of the East Slavic secular authorities, the bearers of the political ideal in the Christian state and society. Emphasizing the fact that the first canonized East Slavic saints arose from the ruling elite itself testifies to two intentions: the desire to underline the strong impact of recently adopted Christianity on decisions of social importance in Kievan Rus', which is intended to prove that it had reached its religious "maturity"; and the striving for a kind of the politically prestigious "sacralization" of the Rurik dynasty, which, with the emergence of saints from its ranks, gained further spiritual legitimacy to rule over the East Slavic territories. Therefore, Boris and Gleb as the first canonized East Slavic saints symbolically mark the beginnings of a new (Christian) period in Rus' history, inextricably linked with the history of the salvation of all mankind.

\section{Passion-bearers in the context of medieval Europe ${ }^{17}$}

As saints, Boris and Gleb were categorized as passion-bearers (сmpacmomepnьubl). In the Orthodox world, this term refers to a specific group of saints characterized by a martyr's death, but not one that would come as a result of hatred against the Christian faith as such; it is instead caused by Christians themselves, usually out of political or material self-interest. (Malmenvall 2015, 205; Kossova 1997, 73-86; Ingham 1984, 40-41) Despite significant dissimilarities with the "classical" martyrs from the first centuries of Christianity, Boris and Gleb were adapted and assimilated into a well-known phenomenon of martyrdom, the earliest widespread form of sainthood in the Mediterranean world. Original or translated (into Church Slavic) entries in liturgical texts and hagiographic compilations appropriated mostly from the Byzantine tradition served as a basis to inspire the development of the native forms of sainthood. (White 2010, 95-96, 101-102, 105) In their writings about the new native saints, the ecclesiastical writers of Rus' found inspiration in the cult of martyrs, also innocent victims of violence, even if under different sociocultural circumstances. The evidence for Boris and Gleb's cult reveals how general and traditional aspects of the Byzantine veneration of martyrs found a new outlet in the two princely brothers. Although new lives of martyrs were no longer being produced in contemporary Byzantium, this type of sainthood proved to be a fruitful model in Rus'. (105) The cult of Boris and Gleb is even more closely connected with the military martyr saints from the third and fourth centuries, such as George and Demetrios, highly esteemed in contemporary Byzantium (during the rule

16 Regarding the concept of salvation history and its patriotic instrumentalization in the context of Kievan Rus', especially concerning the conceptual similarities (or a common conceptual framework) between Ilarion's Sermon, Nestor's Tale and the chronicle Tale of Bygone Years, see Malmenvall (2017; 2015), Ostrowski (2011), and Rychka (2005).

17 The primary aim of this section is not to discuss the extent of the foreign textual models making possible the creation of the Boris and Gleb cycle, but to place the cult of the two princely brothers in the context of European religious and political culture of the time. 
of the Macedonian dynasty) in the function of heavenly protectors of the imperial armies. Military martyr saints were deemed appropriate models for Boris and Gleb (White 2010, 108-110, 112-113; Smirnova 2003, 59), ${ }^{18}$ who combined the military profession ${ }^{19}$ and martyr's deaths-or at least a close approximation thereof-with the protection of peace in their homeland ("saving many lives") and concord within the Rurik dynasty.

In medieval European history, the cult of Boris and Gleb as passion-bearers is not an isolated case; rather, it forms part of the cultural phenomenon of the time and with it constitutes a kind of a subgenre of the martyrological literature. Between around AD 900 and 1100, the veneration of the murdered kings, princes or other members of the ruling dynasties was commonplace on the northern and eastern peripheries of Europe, from England and Scandinavia to Bohemia and Rus. This was the territory where the introduction of the Christian faith at that time was a notable social innovation. In the Byzantine Empire of the time, this phenomenon was unknown; such saints also cannot be found in the South European Latin hagiographies and liturgical texts. The category of murdered rulers or other members of the ruling dynasty as saints was thus typical of those parts of medieval Europe where the new Christian ideals only started to gradually shape the social norms. Almost all ruler or dynastic saints from these territories were, like Boris and Gleb, victims of fellow Christians that were at the same time people close to them (relatives or subjects). All of these saints share the same characteristics: in the face of mortal danger they did not resort to revenge or fratricide as a means of struggle for power, and they courageously accepted their death for the benefit of peace in their homelands. Hagiographies dedicated to passion-bearers focus on the example of their voluntary sacrifice, highlighting the duality between the righteousness of the victim and unfair act of the murderer, as can be seen in the relation between the biblical Abel and Cain. Holy passion-bearers were regarded by their contemporaries as promoters of the new ideal of the Christian ruler or member of the ruling elite and symbols of rejection of the recent pagan past. Their deaths are presented within a framework of confrontation between "exemplary" and "false" Christians (actually still pagans) opposing them. When addressing the subject of passion-bearers, the writers of medieval European peripheries elevate a particular type of sacrifice, defined by following the example of Christ and breaking the cycle of violence, which results in the victim gaining entry into the "Kingdom of Heaven." Testimonies of medieval writers usually confirm the sanctity of these martyrs in two ways: via miraculous healings of ordinary people and via answered prayers for a successful fight against foreign invaders or domestic usurpers. (Paramnova 2010, 281; Klaniczay 2010, 288-289, 302-304; Antonsson 2010, 18; Milyutenko 2006, 9, 14-15, 27-28, 31, 33-35; Hollingsworth 1992, xiv-xv; Ingham 1984, 33, 36-37) In this context, it should be noted that these saints were not canonized for the exactly same reason; their canonizations depended on local social circumstances and political needs. In addition, Boris and Gleb were not rulers (princes of Kiev) in their own right-nevertheless, they were still (regional) princes and members of the ruling dynasty. The comparison between Boris and Gleb and other European saints form the ruling elite is thus applicable to their similar social origin and fate-death by murder at the hand of fellow-Christians out of political or material selfinterest-and their role in fostering the Christian identity of their relatively recently Christianized dynasties and homelands.

18 According to Monica White, the hagiographic and iconographic traditions received from the Byzantine Empire allowed the military martyr saints to gain popularity in Rus'. For example, the early iconography of Boris and Gleb tends to emphasize their identity as soldiers, depicting them wearing armor and holding weapons (swords and/or spears).

19 The socially expected role of the European Medieval princes/rulers could never be separated from their military duties. 
Boris ANd Gleb: Political AND theological implications OF OVERCOMING VIOLENCE THROUGH SACRIFICE IN KIEVAN RUS'

Scholars studying medieval Rus' culture have usually correlated the martyrdom of Boris and Gleb with the fate of the Bohemian prince St. Wenceslaus $(921-935)$ and his grandmother St. Ludmila (died 921). The parallel between Boris and Wenceslaus was apparently already recognized by the East Slavic writers themselves because it is directly present in both the anonymous Tale and Passion and Nestor's Lesson. (Klaniczay 2010, 298-299; Milyutenko 2006, 14, 18, 292; Uspenskiy 2000, 18, 64-65; Senyk 1993, 398-400) According to Ingham (1984, 32-33, 53), the Kievan Rus' literati, who wrote or compiled the Boris and Gleb cycle, appropriated the hagiographic pattern of Wenceslaus (particularly from the First Slavic Life), who died by the hand of his brother Boleslav and through that adjusted the concept of passion bearers to the sociocultural circumstances of their homeland. In this regard, he speaks of "a creative continuity of tradition" (rather than of influence) and emphasizes the existence of cultural intercourse at that time among the East and West Slavs that transcended the incipient confessional allegiance between Constantinople and Rome. According to Ingham, the original East Slavic contribution consists in the kenotic brand of nonresistance and the combined religious and political principle of brotherly love. $(47-50,53)^{20}$ The example of Wenceslaus's and Ludmila's martyrdom is far from being the only one that can be compared with the fate of Boris and Gleb. A similar passion-bearer cult among the Medieval Slavs can be found in the murdered prince Jovan (Ivan) Vladimir of Duklja (Dioclea), who died in 1016 in Prespa in western Macedonia; he was murdered by his cousin Ivan Vladislav, tsar of Bulgaria. ${ }^{21}$

In the context of princely or royal passion-bearers, similar to the case of Boris and Gleb, the death and canonization of Magnus Erlendsson, the jarl (earl) of the Orkney Islands within the Norwegian kingdom, is worth special mention. (33) Earl Magnus of Orkney was assassinated between 1115 and 1117 at the behest of his cousin Haakon, who lured Magnus to the island of Egilsay, where his men lay in ambush. When the conspiracy had been revealed, the earl decided against violent resistance to spare the lives of his men. He went to the church and after the mass voluntarily surrendered to the murderers. The cousin conspirator then ordered Magnus's cook to behead his master. Soon after Magnus's death, miracles supposedly began occurring. In 1135, the local residents demanded the disinterment of his relics, but were opposed by both Earl Paul, Haakon's son, and Bishop Wilhelm (William). Because of his disbelief, the bishop then temporarily lost his sight and, under the strong impression of such a "divine sign," he finally ordered Magnus's tomb to be opened. Magnus was canonized the same year. In the saga of Magnus's martyrdom, some obvious parallels with the texts of the Boris and Gleb cycle can be observed. Magnus, like Boris and Gleb, decided against armed resistance to save the lives of his people. Magnus-like Gleb-was murdered by his own cook. Bishop Wilhelm-like the Kiev metropolitan Georgiinitially questioned the sanctity of the murdered prince. The Boris and Gleb cycle could, in fact, have exerted at least some influence on the authors of the sagas and biographies about Earl Magnus Erlendsson because the ties between Scandinavia (Sweden and Norway) and Kievan Rus' were very vibrant and diverse between the tenth and the thirteenth centuries; at the highest political level, the dynastic marriages are especially worth mentioning. ${ }^{22}$ Therefore, a familiarity with Rus'

20 Contrary to Ingham, Paramonova $(2010,278-280)$ is skeptical about Wenceslaus serving as a textual and conceptual model for the Boris and Gleb cycle. She argues that direct textual borrowings from the Bohemian lives are absent from Rus' texts—there are merely similar motifs or plots; hence, any discussion of such influence remains open to different solutions. Furthermore, according to her, there is no direct information on the territorial or institutional aspects of the veneration of St. Wenceslaus in Kievan Rus.

21 On the case of Jovan Vladimir, see: Polyvianny and Turilov (2010), and Ingham (1987).

22 Confessional differences after the schism between the Western (Catholic) and Eastern (Orthodox) 
literary works can be reasonably assumed. (Antonsson and Garipzanov 2010, 7; Conti 2010, 194-195; Milyutenko 2010, 22-23) Moreover, the phenomenon of the passion-bearers in general and the literary parallels between Earl Magnus and the two Rus' holy princes in particular can be seen as an integral element in active political and cultural interactions across northern and eastern Europe from the tenth to the twelfth centuries. (Antonsson and Garipzanov 2010, 5)

Regarding the typology of the cult of Boris and Gleb and any possible external influence on it, the absence of direct parallels in the Byzantine hagiography makes it necessary to consider a broader European context of princely or royal sainthood. Possible sources of influence have been sought by various scholars in different regions of Western and Eastern Christianity, especially on the northern and eastern peripheries of medieval Europe, where the veneration of holy rulers or members of the ruling dynasties was practiced. These hypotheses are based instead on the possibility of such influences-connected with cultural communication or with the intense diplomatic contacts and far-reaching Rurik dynastic links-than on reliable textual evidence. Nevertheless, a number of studies on the functions and literary discourse of the cult of Boris and Gleb allow modern scholarship to establish some significant parallels with the European dynastic cults. Nonetheless, so far none of these studies can be considered a final solution to the question of whether one can interpret existing similarities as trans-regional parallelisms or (direct) borrowings. (Paramonova 2010, 272-273, 282) In any case, the formation of the cult of Boris and Gleb was conditioned primarily by internal developments in Kievan Rus' society and culture. The cult's emergence reflected specific political consciousness and practices among the members of the ruling dynasty and within the princely clans. ${ }^{23}$ In this political framework, internal dynastic and kinship connections - the interdependence between the (regional) princes from the same dynasty themselves and a specific prince and his druzhina-remained the main model for settling internal disputes. The veneration of Boris and Gleb thus served as a kind of "sacralization" of the ruling dynasty in the sense of showing the practical realization of the (apparently not only nominal) Christian identity of the Rurikids. In hagiographic representation, the internal dynastic and kin relations of the saints were reshaped according to Christian norms and virtues, such as peacefulness, humility, and (brotherly) love. Moreover, these relations acquired their own religious meaning and formed a broader historical and theological framework-that of the salvation history-within which such Christian virtues could be realized and emphasized. (282)

Although Boris and Gleb were related to Yaroslav Vladimirovich and were members of the Rurik dynasty, they were not part of Yaroslav's rule and never held nor wanted to hold the position of the Kievan Prince. In this regard, their veneration, serving as a kind of "sacralization" of the Rurik dynasty, does not draw from their rule over Kievan Rus' (which never existed) in a direct or literal meaning. Rather, it highlights some more general and symbolically far-reaching features of their role in the context of Rus' and salvation history: the desired unity among the members of the Rurik dynasty, the respect for the principle of seniority, and the practical example of the Christian identity of the dynasty, embodied in the sainthood of Boris and Gleb capable of renouncing "earthly glory" for the "Heavenly Kingdom." Furthermore, the veneration of Boris and Gleb spiritually legitimized the rule of Yaroslav Vladimirovich and his descendants. In the sources of the Boris and Gleb cycle, especially in Nestor's Lesson, Yaroslav is depicted as a savior of his father's heritage and a protector of Kievan Rus' from the evil of the "accursed" Sviatopolk-who murdered the innocent princely

Churches in 1054 did not play a major role in the context of political and economic contacts between Scandinavia and Rus'. Regarding the international relations of Kievan Rus', see Nazarenko (2001).

23 For more on the Kievan Rus' political background of the Boris and Gleb cult, see Paramonova (2010, 260-271). 
Boris ANd Gleb: Political AND theological implications OF OVERCOMING VIOLENCE THROUGH SACRIFICE IN KIEVAN RUS'

brothers when they were showing their benevolence and submission to their older brother and thus willing to accept the desired internal dynastic order.

\section{Conclusion}

The princely brothers Boris and Gleb are the first canonized saints of Kievan Rus'. According to the medieval writers, the voluntary sacrifice of the princely brothers was not of merely religious significance; due to its placement in the time of the first Rus' dynastic conflict (1015 - 1019) after the adoption of Christianity, it had a major political connotation. Boris and Gleb respected the will of their elder brother Sviatopolk and thus voluntarily accepted their death in order to prevent further bloodshed and make visible the transience of earthly goods-in this case, political power. The earliest narrative sources belonging to the Boris and Gleb cycle make a symbolic comparison of the fate of the holy brothers with the murder of the Old Testament figure Abel and the redemptive sacrifice of Jesus Christ. At the beginning of the twelfth century, the example of giving one's life for those close to oneself gained a new political and patriotic interpretation. During the period of the growing discord between the Rus' princes, the example of Boris and Gleb served as a foundation for an appeal to end the conflicts within the Rurik dynasty; because of this, they became the "celestial guardians" of their country against both internal and external threats. Emphasizing the fact that the first canonized East Slavic saints arose from the ruling secular elite itself can be seen as a twofold testimony: about the desire to underline the strong impact of recently adopted Christianity on decisions of social importance in Kievan Rus', by which the state supposedly reached its religious "maturity" in the context of salvation history, and about the striving for a kind of politically prestigious "sacralization" of the Rurik dynasty, with the saints having emerged from its ranks allowing it to gain further (symbolic) legitimacy to rule over East Slavic territories.

Although sainthood of this type was unknown in both the Byzantine and southern European Latin Christian worlds, the existence of passion-bearers among the ruling secular elite cannot be considered a peculiarity of Rus' medieval culture. Despite local differences and specific reasons for specific canonizations, the phenomenon of princely or royal passion-bearers was in fact known at that time in countries on the northern and eastern peripheries of Europe that had recently adopted Christianity. At least two cases are worth pointing out: the case of the Bohemian saints Wenceslaus and Ludmila from the first half of the tenth century, and the case of the Norwegian Earl Magnus Erlendsson of Orkney from the beginning of the twelfth century.

\section{REFERENCES}

Abramovich, Dmitriy A. 1916. Жития святых мучеников Бориса и Глеба и служба им [The Lives of the Holy Martyrs Boris and Gleb and the Service Dedicated to them]. Petrograd.

Antonsson, Haki. 2010. The Early Cult of Saints in Scandinavia and the Conversion: A Comparative Perspective. In Haki Antonsson and Ildar H. Garipzanov (eds.). Saints and Their Lives on the Periphery: Veneration of Saints in Scandinavia and Eastern Europe (c. $1000-1200)$. Turnhout, 17-38.

Antonsson, Haki and Garipzanov, Ildar H. 2010. Introduction: The Veneration of Saints in Early Christian Scandinavia and Eastern Europe. In Haki Antonsson and Ildar H. Garipzanov (eds.). Saints and Their Lives on the Periphery: Veneration of Saints in Scandinavia and Eastern Europe (c. 1000 - 1200). Turnhout, 1-14. 
Berend, Nora (ed.). 2007. Christianization and the Rise of Christian Monarchy: Scandinavia, Central Europe and Rus' c. 900 - 1200. Cambridge.

Bugoslavskiy, Sergei A. 2007. Древнерусские литературные произведения о Борисе и Глебе [Rus' Literary Works on Boris and Gleb]. Moscow.

Chichurov, Igor S. 1990. Политисческая идеология средневековья: Византия и Русь [Medieval Political Ideology: Byzantium and Rus']. Moscow.

Conti, Aidan. 2010. Ælnoth of Canterbury and Early Mythopoiesis in Denmark. In Haki Antonsson and Ildar H. Garipzanov (eds.). Saints and Their Lives on the Periphery: Veneration of Saints in Scandinavia and Eastern Europe (c. 1000 - 1200). Turnhout, 189-206.

Fedotov, George P. 1965. The Russian Religious Mind: Kievan Christianity, the Tenth to the Thirteenth Centuries. New York.

Hollingsworth, Paul. 2002. Holy Men and the Transformation of Political Space in Medieval Rus'. In James Howard-Johnston and Paul A. Hayward (eds.) The Cult of Saints in Late Antiquity and the Early Middle Ages: Essays on the Contribution of Peter Brown. Oxford, 187-213.

Hollingsworth, Paul. 1992. The Hagiography of Kievan Rus'. Cambridge MA.

Ingham, Norman W. 1987. The martyrdom of Saint John Vladimir of Dioclea. In International Journal of Slavic Linguistics and Poetics 35/36, 199-216.

Ingham, Norman W. 1984. The Martyred Prince and the Question of Slavic Cultural Continuity in the Early Middle Ages. In Henrik Birnbaum and Michael S. Flier (eds.). Medieval Russian Culture 12. Berkeley, 31-53.

Klaniczay, Gábor. 2010. Conclusion: North and East European Cults of Saints. In Haki Antonsson and Ildar H. Garipzanov (eds.). Saints and Their Lives on the Periphery: Veneration of Saints in Scandinavia and Eastern Europe (c. 1000 - 1200). Turnhout, 283-304.

Kossova, Alda G. 1997. All' alba della cultura russa: La Rus' kieviana (862 - 1240). Roma.

Litvina Anna F. and Uspenskiy, Fyodor B. 2006. Выбор имени у русских князьей в X - XVI вв.: Династическая история сквоз призму антропонимики [Name Selection among Rus' Princes between the Tenth and Sixteenth Century: Dynastic History in the Perspective of Anthroponimics]. Moscow.

Malmenvall, Simon. 2017. Beseda o postavi in milosti metropolita Hilarijona kot primer osmišljanja preteklosti v Kijevski Rusiji. In Zgodovinski časopis 71, 8-29.

Malmenvall, Simon. 2016. Razvoj cerkvene organizacije v Kijevski Rusiji do sredine 12. Stoletja. In Bogoslovni vestnik 76, 547-558.

Malmenvall, Simon. 2015. Kijevska Rusija in Pripoved o minulih letih. In Blaž Podlesnik (ed.). Pripoved o minulih letih. Ljubljana, 175-239.

Milyutenko, Nadezhda I. 2006. Святые князья-мученики Борис и Глеб: Исследование и тексты [Holy Martyr Princes Boris and Gleb: Research and Texts]. Saint-Petersburg.

Müller, Ludolf. 1967. Die altrussischen hagiographischen Erzählungen und liturgischen Dichtungen über die Heiligen Boris und Gleb. Munich.

Nazarenko, Aleksandr V. 2003a. Борис и Глеб. Основные источники [Boris and Gleb. Fundamental Sources]. In Православная энциклопедия [Orthodox Encyclopedia] 6. Moscow, 44-45.

Nazarenko, Aleksandr V. 2003b. Борис и Глеб. Почитание. Почитание Б. и Г. за пределами Руси [Boris and Gleb. Veneration of B. and G. outside Rus']. In Православная энциклопедия [Orthodox Encyclopedia] 6. Moscow, 54-56.

Nazarenko, Aleksandr V. 2001. Древняя Русь на международных путях: междисциплинарные очерки культурных, торговых, политических связей IX - XII веков [Rus' and its International Relations: Interdisciplinary Sketches of Cultural, Commercial, and Political Connections between the Ninth and Twelfth Century]. Moscow. 
Boris ANd Gleb: Political AND theological implications OF OVERCOMING VIOLENCE THROUGH SACRIFICE IN KIEVAN RUS'

Nazarenko, Aleksandr V. and Turilov, Anatoliy, A. 2003. Борис и Глеб. Почитание. Б. и Г. в России [Boris and Gleb. Veneration of B. and G. in Russia]. In Православная энциклопедия [Orthodox Encyclopedia] 6. Moscow, 52-54.

Ostrowski, Donald. 2011. Pagan Past and Christian Identity in the Primary Chronicle. In Ildar H. Garipzanov (ed.). Historical Narratives and Christian Identity on a European Periphery: Early History Writing in Northern, East-Central, and Eastern Europe (c. 1070 - 1200). Turnhout, 229-253.

Ostrowski, Donald. 2004. The Povest' vremennykh let: An Interlinear Collation and Paradosis. Cambridge MA.

Paramonova, Marina. 2010. The Formation of the Cult of Boris and Gleb and the Problem of External Influences. In Haki Antonsson and Ildar H. Garipzanov (eds). Saints and Their Lives on the Periphery: Veneration of Saints in Scandinavia and Eastern Europe (c. 1000 1200). Turnhout, 259-282.

Podskalsky, Gerhard. 1996. Христианство и богословская литература в Киевской Руси (988 1237 гг.) [Christianity and Theological Literature in Kievan Rus' (988 - 1237). Saint-Petersburg. Polyvianny, Dmitriy A. and Turilov, Anatoliy A. 2010. Иоанн Владимир [Ioann/Jovan Vladimir]. In Православная энциклопедия [Orthodox Encyclopedia] 23. Moscow, 736-738.

Poppe, Andrzej. 2003. Земная гибель и небесное торжество Бориса и Глеба [Earthly Death and Heavenly Triumph of Boris and Gleb]. In Труды Отдела древнерусской литературы [Works of the Department of Rus' Literature] 54, 304-336.

Poppe, Andrzej. 1995. О зарождении культа свв. Бориса и Глеба и о посвящённых им произведениях [On Emergence of the Cult of Saint Boris and Gleb and on the Works Dedicated to them]. In Russia Mediaevalis 8, 21-30.

Rowell, Stephen C. 1994. Lithuania Ascending: A Pagan Empire Within East-Central Europe, 1295-1345. Cambridge.

Rychka, Volodymyr. 2005. “Київ-Другий Єрусалім" (з історії политичної думки та ідеологиї середновічної Русі) ["Kiev as the Second Jerusalem” (from the History of Political Thought and Ideology of Medieval Rus')]. Kiev.

Senyk, Sophia. 1993. A History of the Church in Ukraine 1: To the End of the Thirteenth Century. Rome.

Shakhmatov, Alexei A. 2001. Разыскания о русских летописях [Research on the Rus' Chronicles]. Moscow.

Shchapov, Yaroslav N. 2003. Письменные памятники Древней Руси [Written Heritage of Rus']. Saint-Petersburg.

Smirnova, Engelina S. 2003. Борис и Глеб. Иконография. Домонгольский период [Boris and Gleb. Iconography. Pre-Mongol Period]. In Православная энциклопедия [Orthodox Encyclopedia] 6. Moscow, 59.

Uspenskiy, Boris, A. 2000. Борис и Глеб: Восприятие истории в Древней Руси [Boris and Gleb: Reception of History in Rus']. Moscow.

Uzhankov, Aleksandr N. 2011. Историческая поэтика древнерусской словесности [Historical Poetics of Rus' Literacy]. Moscow.

Uzhankov, Aleksandr N. 2000. Святые страстотерпцы Борис и Глеб: к истории канонизации и написания Житий [Holy Passion-Bearers Boris and Gleb: On the History of Canonization and Writing of the Lives]. In Древняя Русь: Вопросы медиевистики [Rus': Questions of Medieval Studies] 1, 28-50.

White, Monica. 2010. Byzantine Saints in Rus' and the Cult of Boris and Gleb. In Haki Antonsson and Ildar H. Garipzanov (eds). Saints and Their Lives on the Periphery: Veneration of Saints in Scandinavia and Eastern Europe (c. 1000 - 1200). Turnhout, 95-114. 
SUMMARY: BORIS AND GLEB: POLITICAL AND THEOLOGICAL IMPLICATIONS OF OVERCOMING VIOLENCE THROUGH SACRIFICE IN KIEVAN RUS. Boris and Gleb were the first canonized East Slavic saints. They were sons of Grand Prince Vladimir Sviatoslavich (980 - 1015), who declared Christianity the state religion of Kievan Rus'. After Vladimir's death, his eldest son Sviatopolk ordered the assassination of his younger brothers Boris and Gleb. Both of them respected the will of their older brother Sviatopolk, voluntarily accepting their violent death. The author of this article acknowledges the generally accepted interpretation that in the East Slavic historical consciousness the sacrifice of Boris and Gleb came to be viewed as a reflection of the sacrifice of the Old Testament figure Abel and as a model of the imitation of Christ concerning the renouncement of secular power. In addition, the author advocates two theses. First, the fact that the first canonized East Slavic saints came from the secular ruling elite testifies to the attempts of the Rus' literati to stress the strong influence of recently adopted Christianity on politically important decisions in Kievan Rus', which allegedly achieved its religious "maturity" within the context of salvation history through this. Second, the existence of the martyrs or passion-bearers among the secular ruling elite, however, cannot be viewed as a specific element of East Slavic medieval culture alone because this type of sainthood was (despite local differences) present in recently Christianized lands on the northern and eastern periphery of Europe at the time.

Doc. dr. Simon Malmenvall

University of Ljubljana

Faculty of Theology

Research Program Group "Ethical and Religious Foundations and Perspectives of Society" Poljanska 4

1000 Ljubljana

Slovenia

Catholic Institute

Faculty of Business Studies

Chair of Philosophy, Religious Studies, and Applied Ethics

Krekov trg 1

1000 Ljubljana

Slovenia

simon.malmenvall@teof.uni-lj.si 